\title{
Consumer attitude towards intention to purchase green foods in chicken meat industry
}

\author{
Toong Foo Weng ${ }^{1, *}$, Aye Aye Khin ${ }^{2}$ \\ ${ }_{1}^{1}$ Faculty of Health and Life Sciences, Management and Science University, Selangor, Malaysia \\ ${ }^{2}$ Faculty of Accountancy and Management, Universiti Tunku Abdul Rahman, Selangor, Malaysia
}

\section{A RT I C LE IN F O}

\section{Article history:}

Received 5 July 2016

Received in revised form

28 October 2016

Accepted 18 November 2016

\section{Keywords:}

Green and Halal foods

Consumer attitude

\begin{abstract}
A B S T R A C T
The aim of this study is to present the consumer attitude towards the intention to purchase green and Halal foods of the chicken meat industry in Malaysia. The major objective is to analyze the factors affecting on intention to purchase towards green and Halal foods of the chicken meat industry in Malaysia. The factor of natural content, convenience, knowledge of Halal and green foods issue, familiarity, price consciousness, attitude towards purchasing and demographic profile are affecting of the intention to purchase green and Halal foods of the chicken meat industry. Simple random sampling and questionnaires were taken to targeting 500 respondents, however, 377 respondents were only qualified. Descriptive Analysis and Analysis of Variance (ANOVA) will be tested into this study. By understanding the attitude, marketers can target the right market and gain profitable.
\end{abstract}

(C) 2017 The Authors. Published by IASE. This is an open access article under the CC BY-NC-ND license (http://creativecommons.org/licenses/by-nc-nd/4.0/).

\section{Introduction}

The concept of halal refers to the manner of producing goods and services in the manner approved by Islamic law or syariah. The halal food industry is thus crucial for Muslims all over the world as it serves to ensure then that the foods items they consume daily are syariah compliant. It is an industry which is set for tremendous growth. With a global Muslim population of 1.8 billion, the market for halal food is estimated at US\$547 billion a year. Muslims are expected to account for $30 \%$ of the world's population by 2025. There are around 1.3 billion Muslims in the world and 1.5 billion halal consumers, which means that one out of every four human being consumes halal products. The difference of 0.2 billion between the halal consumers and Muslims is accounted for by non-Muslims living in Muslims majority countries where most foods are halal, such as Indonesia and Bangladesh. The positive outlook on Malaysia's competitive edge in the halal food industry is echoed by subsequent measures taken by the government.

Green Products are known as environmental friendly products or ecological products (Chen and

\footnotetext{
* Corresponding Author

Email Address: toongfooweng@gmail.com (T. F. Weng) https://doi.org/10.21833/ijaas.2017.04.022

2313-626X/@ 2017 The Authors. Published by IASE.

This is an open access article under the CC BY-NC-ND license

(http://creativecommons.org/licenses/by-nc-nd/4.0/)
}

Chai, 2010). In general, green products are products that will not cause any health hazard to human being and animal; will not include materials derived from the endangered species or threatened environments; will not contribute to excessive waste in its use or packaging; will not harm animals and the products are efficient in its use of resource during manufacture, use and disposal. However, the concept of green is still very new to Malaysian people although green campaign has been carried out for quite sometimes and the market for green products in Malaysia is growing. There is a rising trend of organic food product consumption among consumers all over the world (Mohamad et al., 2014). This rising purchasing pattern is due to the heightened level of consumer awareness on food safety, and health concerns (Mohamad et al., 2014). In Malaysia, organic food still remains a niche market, but one that is growing rapidly. The growing demand can be seen with the increase in the number of organic farming and producers.

For the chicken meat industry in Malaysia, the upstream segment of the supply chain involves breeder farming of grandparent and parent stocks, and the farming of broiler for human consumption. The downstream activities comprise processing of chicken meat, distribution (wholesaling) and final market supply (retailing) of both live broilers and processed chicken products. A key feature of the supply chain is the presence of enterprises that own and operate feed mills, grandparent and parent 
farms (including hatcheries) as well as broiler farms. Such enterprises are referred to as integrators. Malaysia is largely self-sufficient in poultry meat production. Output is expanding slowly, in line with expectations for domestic demand growth. As the primary protein source for a majority of the population, per capita consumption is very high. Almost all feed inputs and most of the genetic stock is imported. All imported poultry meat must be sourced from Government of Malaysia (GOM) approved plants and meet strict Halal slaughter and handling requirements. For the chicken meat industry market, the market is considered to be concentrated when a few businesses in that market hold, respectively and collectively, large market shares. The market share held by a firm may be calculated on the basis of its sales, the number of its customers, its production capacity value added or volume of output.

\section{Theory of planned behavior (TPB)}

The theory of planned behavior is an extension of the theory of reasoned action (Ajzen, 2002) made necessary by the original model's limitation on dealing with behaviors over which people have incomplete volitional control. As in the original theory of reasoned action, a central factor in the theory of planned behavior is the individual's intention to perform a given behavior. Intentions are assumed to capture the motivational factors that influence a behavior; they are indications of how hard people willing to try, of how much of an effort they are planning to exert, in order to perform the behavior, the more likely should be its performance. It should be clear, however, that a behavioral intention can find expression in behavior only if the behavior in question is under volitional control, i.e., if the person can decide at will to perform or not perform the behavior. Although some behaviors may in fact meet this requirement quite well, the performance of most depends at least to some degree on such non-motivational factors as availability of requisite opportunities and resources (e.g. time, money, skills and cooperation of others).

\section{Concept of willing to purchase green products}

Environmentally concerned behavior has been given various names, e.g., eco-friendly behavior, socially responsible behavior, etc., and consumers possessing this behavior have been labeled as green consumers, socially conscious consumers, etc. (Singh, 2009). For the environmentally concerned consumer, reducing current consumption amounts is not the only option today, as green alternatives for many products are available. Providing knowledge on green consumption choices is the onus of the marketers. Although higher price and limited availability may discourage consumption of green products (Orten and Atik, 2009) there is a growing amount of evidence showing that consumers are choosing products or avoiding others based on their impact on the natural environment (Laroche et al., 2001). The green consumer is an opinion leader and a careful shopper who seeks information on products from advertising but is also skeptical about advertising. Marketers might cause consumers to doubt their environmental claims.

\section{Methodology}

The major objective of this study is to investigate the factor affecting on intention to purchase towards green and halal food of chicken meat industry in Malaysia. Moreover, the specific objectives are (i) to estimate the relationship between natural content and convenience; (ii) to analyze knowledge of green and halal food issue and familiarity; (iii) to find out the price consciousness; (iv) to identify the relationship of attitude toward purchasing; and (v) to investigate the relationship of demographic profile towards intention to purchase green and halal food of chicken meat industry in Malaysia.

This study used data collected from a survey which was conducted in Klang Valley area, Malaysia from June 2015. From this study, Bintang Maju Agri (organic chicken seller) will help to interview their customers and all customers are the most appropriate place to collect data because consumers from the all walks of life shop at restaurants. The target population will be (i) supermarkets such as AEON, Jaya Groser; (ii) restaurants and hotels; (iii) wet markets and concept shop; (iv) patient and pregnant women. The target population will be around 20,000 customers. Simple randomized sample of 500 respondents were interviewed by using the structured questionnaires to test their attitude towards green concept. Totally 377 out of 500 the respondents received completely from interviewing. Therefore, total response rate of the study is $75 \%$. The questions were measure by using Likert scale 1 to 5 (1 represent totally disagree and 5 represent totally agree).

This study helps to identify the factors that affecting intention to purchase green and halal food of the chicken meat industry in Malaysia. The diagram shows seven main variables identified from the literature to provide further insights about intention to purchase: natural content $\left(\mathrm{H}^{1}\right)$, convenience $\left(\mathrm{H}^{2}\right)$, knowledge of green and halal food $\left(\mathrm{H}^{3}\right)$, familiarity $\left(\mathrm{H}^{4}\right)$, price consciousness $\left(\mathrm{H}^{5}\right)$ are independent variables and attitudes towards purchasing $\left(\mathrm{H}^{6}\right)$ is indirectly mediating variable, with the purpose of eventually applying them in the marketing strategies.

$\mathrm{H}^{1}, \mathrm{H}^{2}, \mathrm{H}^{3}, \mathrm{H}^{4}, \mathrm{H}^{5}$, and $\mathrm{H}^{6}$ are positively relationship with the intention to purchase green and Halal food of the chicken meat industry.

The null hypothesis in terms of predictor variable is stated as:

$\mathrm{H}^{0}$ : There is no relationship between these factors and intention to purchase green and Halal food of the chicken meat industry.

SPSS (16.0) software was used for analysis of the data. Simple percentages were used for analysis of 
demographic data. Descriptive Analysis and Analysis of variance (ANOVA) was used to determine the factors affecting intention to purchase green and halal foods of chicken meat industry in Malaysia. The ANOVA was conducted in order to find out the impact as well as predictors among the independent variables, i.e., intention to purchase green and halal chicken meat. Fig. 1 shows the conceptual framework of the impact of changing consumer lifestyles on intention to purchase towards green and halal foods in chicken meat industry in Malaysia.

\section{Results and discussions}

The demographic profile of the 377 respondents used in the study is provided in Table 1. A majority of the respondents are females belonging to the age group of 26 to 40 years and having an average monthly income between RM3, 001 to Rm6, 000 . Mostly there are Chinese and their religions are Buddhism. Most of the respondents are in the education of below bachelor. From Table 1, the most purchasers' monthly income is still in the range of RM3,001-RM6,000, it shown to the marketers that position the products in certain status can be one of the important factor. From Table 2, the p-value of the test is less than 0.05 . Hence, at least one pair of means differ significantly. Therefore, the factors of natural content, convenience, knowledge of green and halal foods issue, familiarity, price consciousness, attitude towards purchasing are affecting of the intention to purchase green and halal foods of the chicken meant industry.

Table 1: Demographic profile of the respondents

\begin{tabular}{|c|c|c|}
\hline Characteristics & Number & Percentage $(\%)$ \\
\hline \multicolumn{3}{|l|}{ Gender } \\
\hline Male & 184 & $48.80 \%$ \\
\hline Female & 193 & $51.20 \%$ \\
\hline \multicolumn{3}{|l|}{ Race } \\
\hline Malay & 82 & $21.75 \%$ \\
\hline Chinese & 267 & $70.82 \%$ \\
\hline Indian & 16 & $4.24 \%$ \\
\hline Others & 12 & $3.19 \%$ \\
\hline \multicolumn{3}{|l|}{ Religion } \\
\hline Islam & 86 & $22.81 \%$ \\
\hline Buddhism & 215 & $57.03 \%$ \\
\hline Christianity & 44 & $11.68 \%$ \\
\hline Hinduism & 16 & $4.24 \%$ \\
\hline Others & 16 & $4.24 \%$ \\
\hline \multicolumn{3}{|l|}{ Age } \\
\hline \multicolumn{3}{|l|}{$<25$ years old } \\
\hline $26-40$ years old & $\begin{array}{c}45 \\
157\end{array}$ & $\begin{array}{l}11.94 \% \\
41.64 \%\end{array}$ \\
\hline \multirow[t]{2}{*}{$41-60$ ears } & 135 & $35.81 \%$ \\
\hline & 40 & $10.61 \%$ \\
\hline \multicolumn{3}{|l|}{ Education } \\
\hline Post Graduate & 104 & $27.59 \%$ \\
\hline Degree & 112 & $29.71 \%$ \\
\hline Below Bachelor & 161 & $42.70 \%$ \\
\hline \multicolumn{3}{|l|}{ Monthly Income } \\
\hline RM3,001- & 143 & $37.93 \%$ \\
\hline RM6,000 & 171 & $45.36 \%$ \\
\hline RM6,001- & 51 & $13.53 \%$ \\
\hline RM10,000 & 12 & $3.18 \%$ \\
\hline$>\mathrm{RM} 10,000$ & & \\
\hline
\end{tabular}

Table 2: descriptive analysis and analysis of variance results

\begin{tabular}{|c|c|c|c|c|c|c|}
\hline \multirow{3}{*}{ Natural Content } & & Sum of Squares & $\mathrm{df}$ & Mean Square & $\mathrm{F}$ & Sig. \\
\hline & Between Groups & 67.817 & 4 & 16.954 & 24.056 & .000 \\
\hline & Within Groups & 262.173 & 372 & .705 & & \\
\hline \multirow{4}{*}{ Convenience } & Total & 329.989 & 376 & & & \\
\hline & Between Groups & 48.765 & 4 & 12.191 & 15.200 & .000 \\
\hline & Within Groups & 298.365 & 372 & .802 & & \\
\hline & Total & 347.130 & 376 & & & \\
\hline \multirow[t]{3}{*}{ Knowledge of Halal and Green Foods } & Between Groups & 43.417 & 4 & 10.854 & 15.713 & .000 \\
\hline & Within Groups & 256.970 & 372 & .691 & & \\
\hline & Total & 300.387 & 376 & & & \\
\hline \multirow[t]{3}{*}{ Familiarity } & Between Groups & 103.528 & 4 & 25.882 & 53.832 & .000 \\
\hline & Within Groups & 178.854 & 372 & .481 & & \\
\hline & Total & 282.382 & 376 & & & \\
\hline \multirow[t]{3}{*}{ Price Consciousness } & Between Groups & 52.202 & 4 & 13.050 & 41.343 & .000 \\
\hline & Within Groups & 117.427 & 372 & .316 & & \\
\hline & Total & 169.629 & 376 & & & \\
\hline \multirow[t]{3}{*}{ Attitude towards Purchasing } & Between Groups & 65.104 & 4 & 23.450 & 59.212 & .000 \\
\hline & Within Groups & 224.356 & 372 & .112 & & \\
\hline & Total & 289.460 & 376 & & & \\
\hline
\end{tabular}

\section{Conclusion}

Several perspective regarding factors affecting on consumer attitude towards the intention to purchase green and halal foods of chicken meat industry in Malaysia have been discussed. While in Malaysia, the findings showed that consumer buys green and halal chicken meat because of these is natural content, convenience, halal issue and reasonable price in the chicken meat consumption. The implication of this conceptual research can also be used for future study to derive marketing strategies that will encourage more consumes to opt for and consume more healthy chicken as their main choice of food type.

By improving the public awareness, it will increase confident intention purchasing towards the halal chicken meat. Moreover, the confident with the Halal foods with the demographic factors and attitude towards purchasing are the factors affecting 
the decision of purchasing. Thus, the combination of these issues needs to be considered by the producers in order to make the business and industry successful. The green business became the niche market and profitable business, as consumers are more awareness about the health and environmental issue. As the results, by having a good performance of green/organic poultry production, contrasting alternative systems for producing green/organic poultry, and free-range and barn production system, it is significant growth in the market for green/organic poultry products. Last but not least, the demand of those products is high especially able to target the right markets and gain profitable.

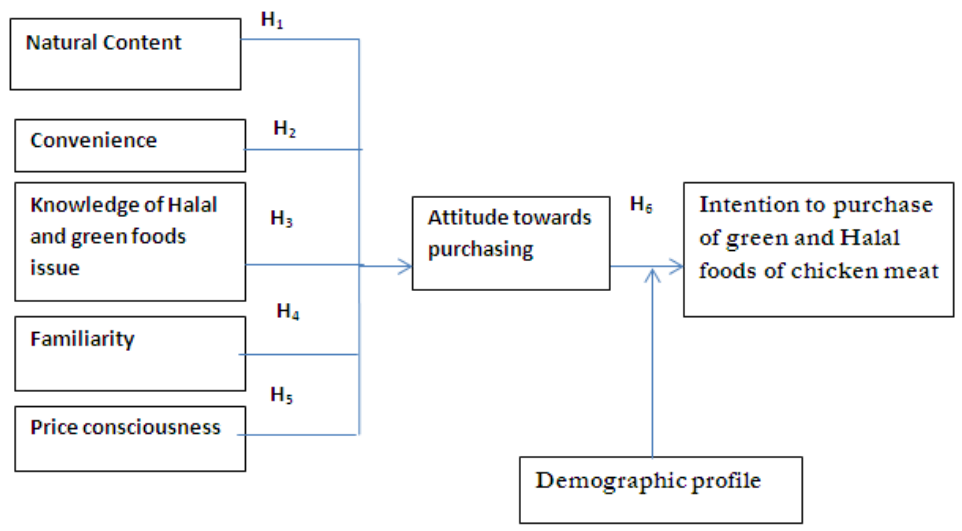

Fig. 1: Conceptual framework of consumer attitude towards to the intention to purchase Green and Halal foods of chicken meat industry in Malaysia

\section{References}

Ajzen I (2002). Perceived behavioural control, self-efficacy, locus of control, and the theory of planned behaviour. Journal of Applied Social Psychology, 32(4): 665-683.

Chen TB and Chai LT (2010). Attitude towards the environment and green products: Consumers' perspective. Management Science and Engineering, 4(2): 27-39.

Laroche M, Bergeron J, and Barbaro-Forleo G (2001). Targeting consumers who are willing to pay more for environmentally friendly products. Journal of Consumer Marketing, 18(6): 503520 .
Mohamad SS, Rusdi SD, and Hashim NH (2014). Organic food consumption among urban consumers: preliminary results. Procedia-Social and Behavioral Sciences, 130: 509-514.

Orten T and Atik D (2009). Environmentally friendly consumption preferences: Understanding the impact of consumption routines. NA-Advances in Consumer Research, 36: 822-824.

Singh N (2009). Exploring socially responsible behaviour of Indian consumers: An empirical investigation. Social Responsibility Journal, 5(2): 200-211. 